\title{
Involvement of oxidative stress in the mechanism of p,p'-DDT-induced nephrotoxicity in adult rats
}

\author{
Neila Marouani ${ }^{1}$, Dorsaf Hallegue ${ }^{1}$, Mohsen Sakly $^{1}$, Moncef Benkhalifa ${ }^{2}$, Khémais Ben Rhouma ${ }^{1}$ \\ and Olfa Tebourbi ${ }^{1}$ \\ ${ }^{1}$ Laboratory of Integrated Physiology, Faculty of Sciences, Bizerte, Carthage University, Jarzouna, Tunisia \\ ${ }^{2}$ Reproductive Medicine and Medical Cytogenetics Department, Regional University Hospital and School of Medicine, Picardie \\ University Jules Verne, Amiens, France
}

\begin{abstract}
The 1,1,1-trichloro-2,2-bis(4-chlorophenyl) ethane (p,p'-DDT) is an organochlorine pesticide that persists in the environment and has a risk to human health. We investigated whether p,p'-DDT-induces nephrotoxicity in rats and whether oxidative stress and apoptosis are involved in the pathogenesis of this process. Male rats received the pesticide at doses of 50 and $100 \mathrm{mg} / \mathrm{kg}$ for 10 days. Renal damage was evaluated by histopathological examination and serum markers. The oxidative stress was evaluated by lipid peroxidation (LPO), metallothioneins (MTs) and protein carbonyl levels. Antioxidant enzymes were assessed by determination of superoxide dismutase (SOD) and catalase (CAT) activities. Glutathione-dependent enzymes and reducing power in kidney were evaluated by glutathione peroxidase (GPx), glutathione reductase (GR), glutathione S-transferase (GST) activities. Renal tubular cells apoptosis was assessed through the TUNEL assay. After 10 days of treatment, an increase of serum creatinine and urea levels occurred, LPO and protein carbonyl levels were increased, while MTs level, SOD and CAT activities were decreased. Besides, the GPx, GR, GST, and GSH activities were decreased. Histological alterations in kidney tissue and intense apoptosis in renal tubular cells were observed. These results suggest that DDT sub-acute treatment causes oxidative stress and apoptosis, which may be the chief mechanisms of DDT-induced nephrotoxicity.
\end{abstract}

Key words: Apoptosis - Histopathology — Kidney - Oxidative stress - p,p'DDT - Rat

\begin{abstract}
Abbreviations: CAT, catalase; GPx, glutathione peroxidase; GR, glutathione reductase; GSH, reduced glutathione; GSSG, oxidized glutathione; GST, glutathione S-transferase; $\mathrm{H}_{2} \mathrm{O}_{2}$, hydrogen peroxide; LPO, lipid peroxidation; MDA, malondialdehyde; MTs, metallothioneins; PBS, phosphate-buffered saline; (p,p'-DDT), 1,1,1-trichloro-2,2-bis(4-chlorophenyl)ethane; ROS, reactive oxygen species; SOD, superoxide dismutase.
\end{abstract}

\section{Introduction}

Organochlorine pesticides are organic compounds that persist in the environment, bioaccumulate through the food chain and have a risk of causing adverse effects to human health and environment. These pesticides are characterized

Correspondence to: Khémais Ben Rhouma, Laboratory of Integrated Physiology, Faculty of Sciences, Bizerte, Carthage University, Jarzouna, Tunisia

E-mail: k.benrhouma2015@gmail.com by their cyclic structure, number of chlorine atoms and low volatility (Ledirac et al. 2005). The 1,1,1-trichloro-2,2bis(4-chlorophenyl)ethane (p,p'-DDT), was the most used organochlorine pesticide in the world. It was synthesized in 1874 and was discovered to be an effective insecticide in 1939. It was first used mainly to protect military areas and personnel from vector-borne diseases such as malaria, but later began to be used widely as an agricultural insecticide in the world (Spencer and Schaumburg 2000). The use of p,p'-DDT in the most western countries was banned in 1970s due to its adverse effects on wildlife. However, $p, p^{\prime}$-DDT and 
its main metabolite 1,1-dichloro-2,2-bis(4-chlorophenyl) ethane (p,p'-DDE) are still persistent in the environment, both because of their long half life and due to atmospheric drift from countries that continue to use DDT as an insecticide. Approximately $80 \%$ of the DDT analogs found in human fat and $40 \%$ of DDT analogs found environmentally are DDE (WHO, 1979). Also, numerous analytical studies showed higher levels of DDT and DDE than the allowable daily intake in food (Muralidharan et al. 2009), adipose tissues (Aulakh et al. 2007) and maternal milk (Malarvannan et al. 2009) all over the world. Evidence accumulated over the years has suggested that chronic exposure to DDT and its derivatives is associated with loss weight, anorexia, sterility, endocrine disruptions, muscular weakness, tremors, hepatic effects, and anemia in humans (Hillman 1998; Spencer and Schaumburg 2000). On the other hand, it has been reported that oxidative stress can be used as a biomarker to evaluate damages and a possible mechanism of DDT and DDE toxicity in humans (Frigo et al. 2005; Jin et al. 2014). Furthermore, oxidative stress is one of the best known causes of cellular damage, mostly due to the formation of free radicals that damage cell DNA (Wu and Bratton 2013). Previous studies have indicated that the nephrotoxicity and hepatotoxicity induced by organochlorine pesticides may be associated with the enhanced production of reactive oxygen species (ROS) (Shah and Iqbal 2010; Vijaya Padma et al. 2011). The effects of p,p'-DDT have already been investigated in several studies (Shi et al. 2010; Tebourbi et al. 2010; Jin et al. 2014), but results concerning its eventual nephrotoxic effects are very limited. Therefore, the aim of the present study was to investigate the effect of p,p'-DDT subacute treatment on rat kidney function and the implication of oxidative stress and apoptosis in this organ. To this end, renal biomarkers such creatinine and urea levels were assessed. The status of the oxidative stress was evaluated by biomarkers such lipid peroxidation (LPO), metallothioneins (MTs) and protein carbonyl levels. Antioxidant enzymes such as superoxide dismutase (SOD) and catalase (CAT) activities were measured. In addition, glutathione-dependent enzymes and reducing power in kidney were evaluated. The histological analysis and the detection of apoptotic cells by TUNEL assay in kidney were aimed to be examined.

\section{Materials and Methods}

\section{Animals and reagents}

Male Wistar rats (50 days of age) were purchased from the Tunisian Company of Pharmaceutical Industries (SIPHAT, Rades, Tunis, Tunisia). The rats were housed under controlled conditions of temperature $\left(25^{\circ} \mathrm{C}\right)$ with a constant day/night cycle (light from 8:00 to 20:00). Food and water were provided ad libitum. DDT (98\%) were purchased from Sigma Chemical (St. Louis, MO, USA). Rats were randomized into four experimental groups of approximately similar weight $(n=8)$ as follows: Group 1 (Control), rats received equal daily volumes of vehicle (corn oil) during 10 days; Group 2 (DDT 50), animals received daily an intraperitoneal (i.p.) injection of DDT diluted with corn oil at a dose of $50 \mathrm{mg} / \mathrm{kg}$ body weight (b.w.) during 10 days; Group 3 (DDT 100), animals were administered 10 daily injections of $100 \mathrm{mg} \mathrm{DDT} / \mathrm{kg}$ b.w.; Group 4 (DDT+VitC), animals were i.p. injected by $100 \mathrm{mg}$ of DDT/kg b.w. followed by vitamin C (200 mg/kg b.w.) during the treatment period (Aksoy et al. 2005). The choice of the dosing period and DDT doses was based on the results of previous studies (Ben Rhouma et al. 2001; Harada et al. 2003; Tebourbi et al. 2010). L-ascorbic acid (vitamin C) used in this study were purchased from Sigma chemicals (Aldrich Chemical Company). Rats were fed and observed daily. The body weight of rats was determined daily through the experiment. After 10 days of treatment, all animals were killed by decapitation, the left kidney were dissected and weighed. Animals were cared for in compliance with the code of practice for the Care and Use of Animals for Scientific Purposes. Approval for these experiments was obtained from the Medical Ethical Committee for the Care and Use of Laboratory Animals of Pasteur Institute of Tunis (approval number: LNFP/Pro 152012). The experimental protocols were approved by the Faculty Ethics Committee (Faculté des Sciences de Bizerte, Tunisia).

\section{Tissue preparation}

Fractions of kidney (400 mg) from control and treated groups were homogenized in phosphate-buffered saline (PBS, pH 7.2). The homogenates were centrifuged at $600 \times g$ for $10 \mathrm{~min}$ and recentrifuged at $13,000 \times g$ for $20 \mathrm{~min}$ at $+4^{\circ} \mathrm{C}$ to obtain a postnuclear homogenate and postmitochondrial supernatant fraction (Beytut and Aksakal 2003).

\section{Renal biomarkers assay}

Serum was collected by centrifugation $(4000 \times g$ for $15 \mathrm{~min})$. The levels of creatinine and urea in serum were assayed spectrophotometrically according to the standard procedures using commercially available diagnostic kits (Chronolab, France).

\section{Malondialdehyde assay}

Lipid peroxidation was measured in the kidney using thiobarbituric acid reacting substance (TBARS) following the method of Buege and Aust (1976) and was expressed in terms of malondialdehyde (MDA) contents. 


\section{Measurement of metallothioneins}

Determination of MTs was performed according to the technique described by Eaton and Cherian (1991).

\section{Protein carbonyl assay}

Protein carbonyl content was assayed by the procedure of Levine et al. (1990) as modified by Parvez and Raisuddin (2005). Soluble protein $(0.5 \mathrm{ml})$ was reacted with $10 \mathrm{mM}$ $\mathrm{DNPH}$ in $2 \mathrm{M}$ hydrochloric acid for $1 \mathrm{~h}$ at room temperature and precipitated with $6 \%$ trichloroacetic acid (TCA). The pelleted protein was washed by resuspension in ethanol/ethyl acetate (1:1). Proteins were then solubilized in $6 \mathrm{M}$ guanidine hydrochloride, $50 \%$ formic acid and centrifuged at 16,000 $\times g$ for 5 min to remove any trace of insoluble material. The carbonyl content was measured spectrophotometrically at $366 \mathrm{~nm}$. Assay was performed in triplicate and a tissue blank incubated with $2 \mathrm{M} \mathrm{HCl}$ without DNPH was included for each sample. The results were expressed as nanomoles of protein carbonyls/mg protein based on the molar extinction coefficient of $21 \mathrm{M}^{-1} \cdot \mathrm{cm}^{-1}$.

\section{Determination of antioxidant enzymes activities}

\section{Superoxide dismutase activity}

The method described by Marklund and Marklund (1974) was used for assay of superoxide dismutase (SOD) activity. Briefly, the assay mixture contained $2.4 \mathrm{ml}$ of $50 \mathrm{mM}$ tris- $\mathrm{HCl}$ buffer containing $1 \mathrm{mM}$ EDTA ( $\mathrm{pH} 7.6$ ), $300 \mu \mathrm{l}$ of $0.2 \mathrm{mM}$ pyrogallol and $300 \mu \mathrm{l}$ enzyme source. The increase in absorbance was measured immediately at $420 \mathrm{~nm}$ against blank containing all the components except the enzyme and pyrogallol at $10 \mathrm{~s}$ intervals for $3 \mathrm{~min}$ on a Systronics Spectrophotometer. The enzyme activity was expressed as units per mg of protein.

\section{Catalase activity}

The catalase activity was measured according to the method of Aebi (1984). Activity was assayed by determining the rate of degradation of $\mathrm{H}_{2} \mathrm{O}_{2}$ at $240 \mathrm{~nm}$ in $10 \mathrm{mM}$ of potassium phosphate buffer ( $\mathrm{pH} 7.0)$. An extinction coefficient of $0.036 \mathrm{mM} / \mathrm{cm}$ was used for calculations. The enzyme activity was expressed as nmol of $\mathrm{H}_{2} \mathrm{O}_{2}$ consumed per minute per $\mathrm{mg}$ of protein.

\section{Glutathione-dependent enzymes and reducing power}

\section{Glutathione peroxidase activity}

GPx generation was assayed by the method of Paglia and Valentine (1967). The assay mixture contained $1.59 \mathrm{ml}$ of phosphate buffer (100 mM, pH 7.6), $100 \mu$ of EDTA $(10 \mathrm{mM}), 100 \mu \mathrm{l}$ of sodium azide, $50 \mu \mathrm{l}$ of glutathione reductase, $100 \mu \mathrm{l}$ of reduced glutathione, $100 \mu \mathrm{l}$ of NADPH (200 mM), $10 \mu \mathrm{l}$ of $\mathrm{H}_{2} \mathrm{O}_{2}$ and $10 \mu \mathrm{l}$ enzyme source. Disappearance of NADPH was measured immediately at $340 \mathrm{~nm}$ against blank containing all the components except the enzyme at $10 \mathrm{~s}$ intervals for $3 \mathrm{~min}$ on a Systronics Spectrophotometer. One unit was defined as $1 \mathrm{nM}$ of NADPH oxidized per minute and the specific activity was reported as units per mg of protein.

\section{Glutathione reductase activity}

GR activity was determined as described by Calberg and Mannervik (1985). In this assay, glutathione oxidized is reduced by GR at the expense of NADPH consumption, which is followed at $340 \mathrm{~nm}$. GR activity is proportional to NADPH decay. GR activity was expressed as units per mg of protein.

\section{Glutathione S-transferase activity}

GST activity was measured using the method of Habig et al. (1974). Briefly, $1 \mathrm{mM}$ of 1-chloro-2,4-dinitrobenzene (CDNB) was added to buffer containing $1 \mathrm{mM}$ GSH and an aliquot of sample to be tested. Upon addition of CDNB, the change in absorbance at $340 \mathrm{~nm}$ was measured as a function of time. The extinction coefficient for this reaction is $9.6 \mathrm{mM}^{-1} \cdot \mathrm{cm}^{-1}$. GST activity was expressed as $\mu \mathrm{mol}$ CDNB conjugates $/ \mathrm{min} / \mathrm{mg}$ protein and was reported as units per mg of protein.

\section{Determination of reduced and oxidized glutathione}

The levels of reduced and oxidized glutathione (GSH and GSSG) were estimated as described by Hissin and Hilf (1976). Briefly, GSH in the acid soluble supernatant fraction of kidney cells was reacted with $o$-phthaldialdehyde at $\mathrm{pH} 8.0$ to yield a highly fluorescent cyclic product, while GSSG was determined by the same reagent but at $\mathrm{pH} 12$ and in the presence of N-ethylmaleimide. GSH and GSSG contents were expressed as nmol per mg protein, which allowed the calculation of the glutathione redox ratio (GSSG/GSH).

\section{Histological analysis}

Thin slices of kidney tissue with cortex and medulla were fixed overnight at room temperature by direct immersion in $4 \%$ paraformaldehyde in $0.1 \mathrm{M}$ phosphate buffer, $\mathrm{pH}$ 7.4. The samples were dehydrated with ethanol and toluene series and embedded in paraffin. Serial sections $(4 \mu \mathrm{m})$ were mounted on gelatin-coated glass slides cut and stained with haematoxylin and eosin. 


\section{Detection of apoptotic cells by TUNEL assay}

The kidney tissues were fixed overnight at room temperature by direct immersion in $4 \%$ paraformaldehyde in $0.1 \mathrm{M}$ phosphate buffer, $\mathrm{pH}$ 7.4. The samples were dehydrated with ethanol and toluene and embedded in paraffin wax. Serial sections ( $4 \mu \mathrm{m}$ thick) were mounted on gelatin-coated glass slides and stained with TUNEL (TdT-mediated dUTPdigoxigenin Nick and Labeling). After deparaffinization and rehydration, tissues sections were incubated with $0.1 \%$ (v/ v) Triton X-100 for 2 min on ice, followed by washing of the slides twice in $\mathrm{PBS}\left(\mathrm{CaCl}_{2} \times 2 \mathrm{H}_{2} \mathrm{O} 0.8 \mathrm{mM}, \mathrm{KCl} 2.6 \mathrm{mM}\right.$, $\mathrm{KH}_{2} \mathrm{PO}_{4} 1.4 \mathrm{mM}, \mathrm{MgCl}_{2} \times 6 \mathrm{H}_{2} \mathrm{O} 0.4 \mathrm{mM}, \mathrm{NaCl} 136 \mathrm{mM}$, $\mathrm{Na}_{2} \mathrm{HPO}_{4} 8 \mathrm{mM}, \mathrm{pH} 7.2$ ). The specimens were then incubated one hour at $37^{\circ} \mathrm{C}$ in a solution consisting of $1 \mathrm{mM}$ cobalt chloride, $140 \mathrm{mM}$ sodium cacodylate and terminal deoxyribonucleotidyl transferase (TdT) at a final concentration of $0.1 \mathrm{U} / \mu \mathrm{l}$ to insert biotin-16-dUTP at the 3'-ends of DNA fragments. A streptavidin-peroxidase complex and 3-amino-9-ethylcarbazole served as the detection system for biotin. The slides were washed in PBS, developed with $0.05 \%$ diaminobenzidine, and stained for $15 \mathrm{~min}$ at room temperature. Sections were lightly counter-stained with hematoxylin and mounted in glycerin jelly. Negative control included omission of TdT from the labelling mixture. The positively labeled cells appear as darkly brown stained. Twenty fields in five sections per kidney were sampled randomly in the cortex and outer stripe of the outer medulla. The apoptotic index was calculated, using Image-Pro Plus version 4.5 software (Media Cybernetics Inc., Silver Spring, MD, USA) at $\times 400$ magnification, on the basis of previous report (Luo et al. 2008):

Apoptotic index $(\%)=$ (number of positive cells/total number of cells) $\times 100$.

\section{Statistical analysis}

Data were analyzed using Statistica for Windows version 5.0 Software. Overall differences in mean values between control and treatment groups were measured using one-way analysis of variance (ANOVA) followed by Turkey's multiple comparison as the post hoc test. The results were expressed as means \pm standard errors of the mean (SEM) and differences were considered statistically significant at $p<0.05$.

\section{Results}
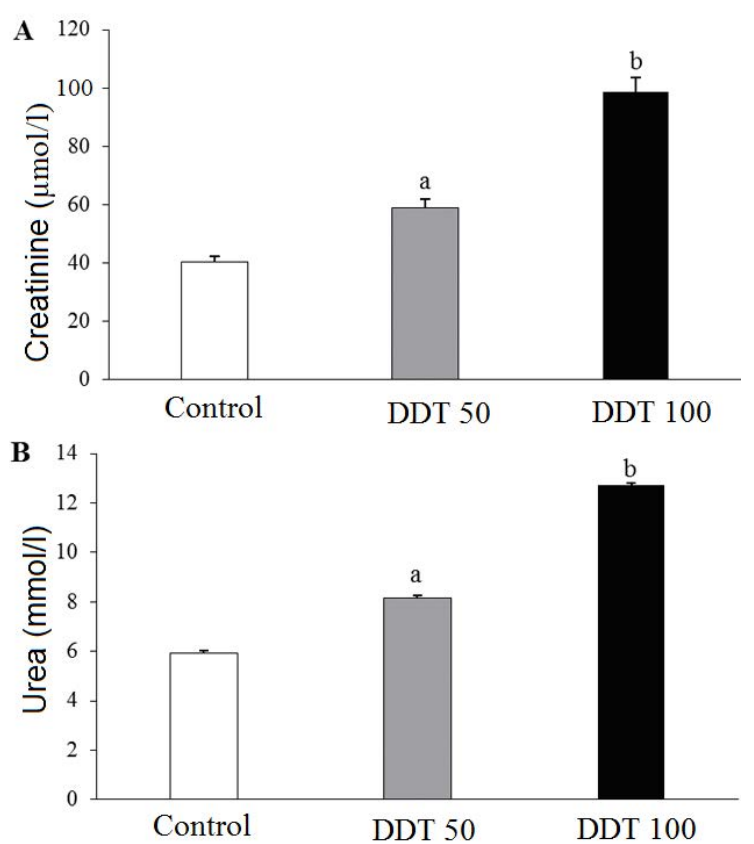

Figure 1. Effect of DDT treatment on serum creatinine (A) and urea (B) levels of adult rat. Each value is the mean of 8 determinations with standard error (SEM). Rats received an i.p. injection of 50 (DDT 50) or 100 (DDT 100) $\mathrm{mg} / \mathrm{kg}$ body weight of DDT during 10 days. Control animals received the vehicle. ${ }^{\mathrm{a}, \mathrm{b}} p<0.05$ compared with controls (Tukey's multiple comparison post hoc test).

\section{Renal biomarkers}

Renal biomarkers levels of control and treated rats are given in Fig. 1. Exposure of rats to DDT for 10 consecutive days induced a significant increase in serum level of creatinine in treated rats compared to control groups (Fig. 1A). This increase was about $46 \%$ and $143 \%$ of controls for DDT 50 and DDT 100, respectively. An increase of serum urea level was also observed in treated rats. This increase was of $37.8 \%$ and $114 \%$, respectively with DDT 50 and DDT 100 (Fig. 1B).

\section{MDA, protein carbonyl and MTs}

DDT treatment significantly raised MDA levels in a dosedependent manner from $2.16 \pm 0.13 \mathrm{nmol} / \mathrm{mg}$ protein to $2.29 \pm 0.17 \mathrm{nmol} / \mathrm{mg}$ prot. and $4.54 \pm 0.48 \mathrm{nmol} / \mathrm{mg}$ prot., respectively, for DDT 50 and DDT 100 (Fig. 2). Our result indicated that co-administration of vitamin $\mathrm{C}$ with DDT modulated significantly the level of MDA concentration to normal control (Fig. 2). The content of protein carbonyl in kidney increased from $1.68 \pm 0.22$ to $2.93 \pm 3.17$ and $4.33 \pm 0.42 \mathrm{nmol} / \mathrm{mg}$ prot., respectively, for DDT 50 and DDT 100 groups (Fig. 3). In contrast, the level of MTs in kidney was significantly decreased in treated rats with the high dose (100 mg of DDT/kg). This decrease was about $51.7 \%$ compared with the control group (Fig. 4). 


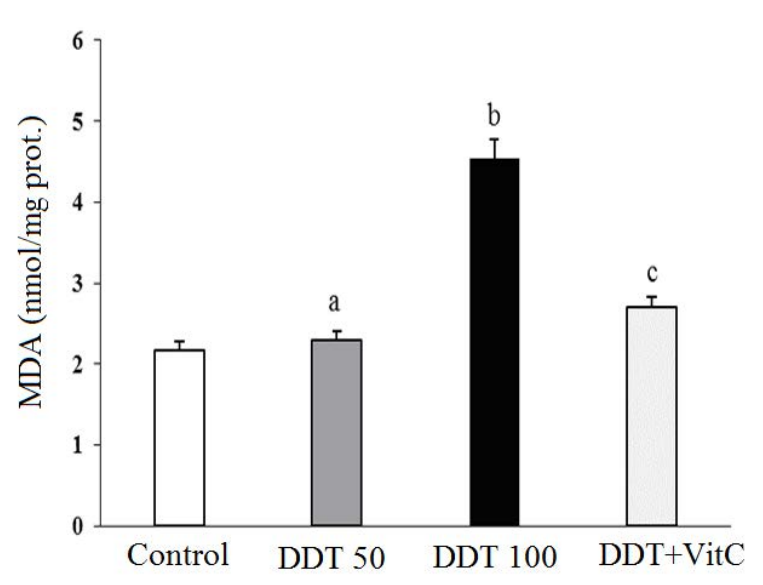

Figure 2. Effect of DDT and vitamin $\mathrm{C}$ on the concentration of malondialdehyde in kidney of adult rat. Each value is the mean \pm SEM of 8 determinations in duplicate per group. Rats received an i.p. injection of 50 (DDT 50) or 100 (DDT 100) $\mathrm{mg} / \mathrm{kg}$ body weight of DDT during 10 days. DDT+VitC: rats received an i.p. injection of $100 . \mathrm{mg}$ of DDT/ $\mathrm{kg}$ followed by vitamin C ( $200 \mathrm{mg} / \mathrm{kg})$. Control animals received the vehicle. DDT treatment was preformed as described in the methods section. ${ }^{\mathrm{a}, \mathrm{b}} p<0.05$ compared with controls (Tukey's multiple comparison post hoc test). ${ }^{\mathrm{c}} p<0.05$ compared with DDT 100 group (Tukey's multiple comparison post hoc test).

\section{Antioxidant enzyme activities}

The antioxidant enzymes activities in kidney are presented in Fig. 5. The SOD activity was significantly reduced with the highest dose by $46.5 \%$ of control (Fig. 5A). DDT treatment significantly reduced CAT activity $(114.8 \pm 3.4$ and 74 $\pm 4.8 \mathrm{nmol} / \mathrm{H}_{2} \mathrm{O}_{2} / \mathrm{min} / \mathrm{mg}$ prot., respectively, with DDT 50

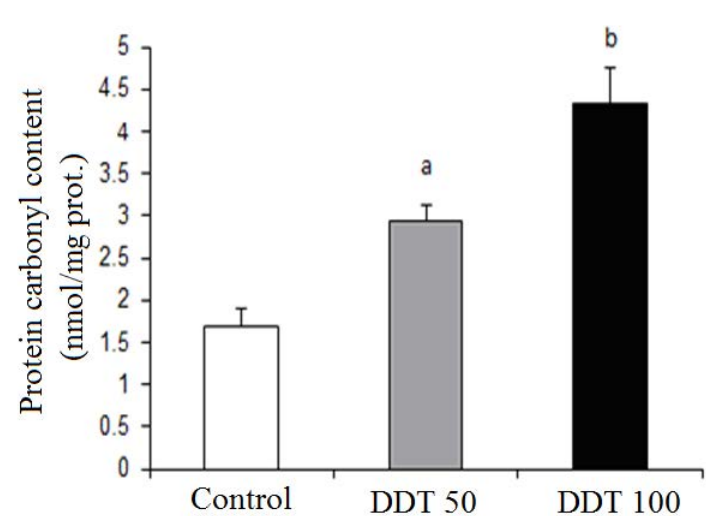

Figure 3. Effect of DDT treatment on kidney protein carbonyl content in adult rat. Each value is the mean \pm SEM of 8 determinations. Rats received an i.p. injection of 50 (DDT 50) or 100 (DDT 100) mg/ $\mathrm{kg}$ body weight of DDT during 10 days. Control animals received the vehicle. ${ }^{\mathrm{a}, \mathrm{b}} p<0.05$ compared with controls (Tukey's multiple comparison post hoc test). and DDT 100 versus $157.3 \pm 4.1 \mathrm{nmol} / \mathrm{H}_{2} \mathrm{O}_{2} / \mathrm{min} / \mathrm{mg}$ prot.) in a dose-dependent manner (Fig. 5B).

\section{Glutathione-dependent enzymes and reducing power}

Glutathione-dependent enzymes and reducing power in kidney are presented in Table 1 . The GPx activity increased with the dose of $50 \mathrm{mg} / \mathrm{kg}$ by $18 \%$ and declined with the highest dose by $48.6 \%$ of control. Also, the GST activity in kidney increased with the dose of $50 \mathrm{mg} / \mathrm{kg}$ by $62.4 \%$ and declined with the highest dose by $20.4 \%$ of control. The GR activity was not affected in the DDT 50 group but was significantly decreased in DDT 100 group by $44.9 \%$ of control. GSH level was significantly decreased in treated rats compared to control groups. This decrease reached $19 \%$ and $38.8 \%$ of controls for DDT 50 and DDT 100, respectively. In contrast, DDT treatment induced a dose-dependent increase in GSSG levels. This increase reached $51.4 \%$ and $122.5 \%$ of controls for DDT 50 and DDT 100, respectively. The ratio between concentrations of GSSG and GSH is a valuable marker, characterizing cellular redox status. Thus, exposure to DDT significantly increased the ratio GSSG/GSH in treated rats compared to control groups. This increase reached $87.5 \%$ and $275 \%$ of controls for DDT 50 and DDT 100, respectively.

\section{Histopathological examination}

Histopathological analysis of kidney tissue sections (cortex and medulla) of rats exposed to DDT showed abnormalities as compared to the control. Kidney of control rats exhibited a normal renal cortex with proximal and distal convoluted tubules surrounding renal corpuscles with normal Bowman's space and blood vessels (Fig. 6A, B). In contrast, kidney of

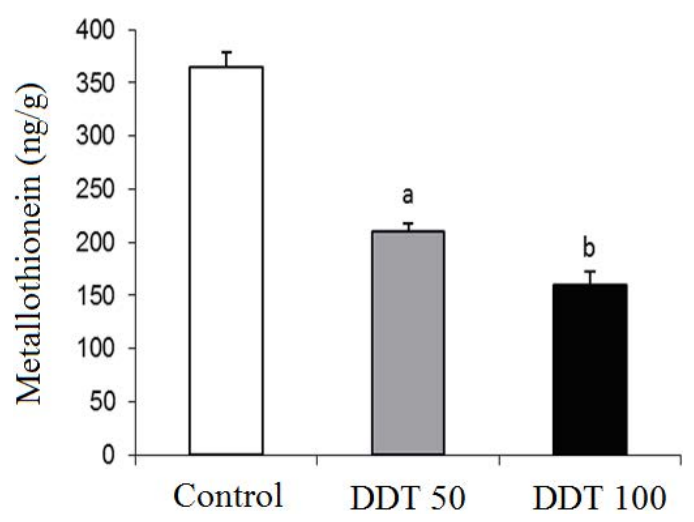

Figure 4. Effect of DDT treatment on kidney metallothionein concentration in adult rat. Each value is the mean \pm SEM of 8 determinations. Rats received an i.p. injection of 50 (DDT 50) or 100 (DDT 100) $\mathrm{mg} / \mathrm{kg}$ body weight of DDT during 10 days. Control animals received the vehicle. ${ }^{\mathrm{a}, \mathrm{b}} p<0.05$ compared with controls (Tukey's multiple comparison post hoc test). 
Table 1. Effect of DDT treatment on glutathione-dependent enzymes and reducing power in kidney of adult rat

\begin{tabular}{lccr}
\hline Parameters & Control & DDT 50 & DDT 100 \\
\hline GPx (U/mg Pt) & $5.51 \pm 0.2$ & $6.51 \pm 0.35^{\mathrm{a}}$ & $2.83 \pm 0.17^{\mathrm{b}}$ \\
GR (U/mg Pt) & $3.43 \pm 0.16$ & $3.26 \pm 0.12$ & $1.89 \pm 0.16^{\mathrm{a}}$ \\
GST (U/mg Pt) & $50.35 \pm 1.76$ & $81.79 \pm 2.95^{\mathrm{a}}$ & $40.05 \pm 2.57^{\mathrm{b}}$ \\
GSH (nmol/mg Pt) & $98.91 \pm 5.66$ & $80.1 \pm 4.9^{\mathrm{a}}$ & $60.54 \pm 2.51^{\mathrm{b}}$ \\
GSSG (nmol/mg Pt) & $15.99 \pm 0.98$ & $24.22 \pm 1.07^{\mathrm{a}}$ & $35.59 \pm 2.41^{\mathrm{b}}$ \\
GSSG/GSH (\%) & $0.16 \pm 0.01$ & $0.30 \pm 0.01^{\mathrm{a}}$ & $0.6 \pm 0.05^{\mathrm{b}}$ \\
\hline
\end{tabular}

Each value is the mean \pm SEM of 8 determinations. Rats received an i.p. injection of 50 (DDT 50) or 100 (DDT 100) mg/kg body weight of DDT during 10 days. Control animals received the vehicle. Gpx, glutathione peroxidase; GR, glutathione reductase; GST, glutathione S-transferase; GSH, reduced glutathione; GSSG, oxidized glutathione. ${ }^{\mathrm{a}} p<0.05 ;{ }^{\mathrm{b}} p<0.01$ compared with controls (Tukey's multiple comparison post hoc test).
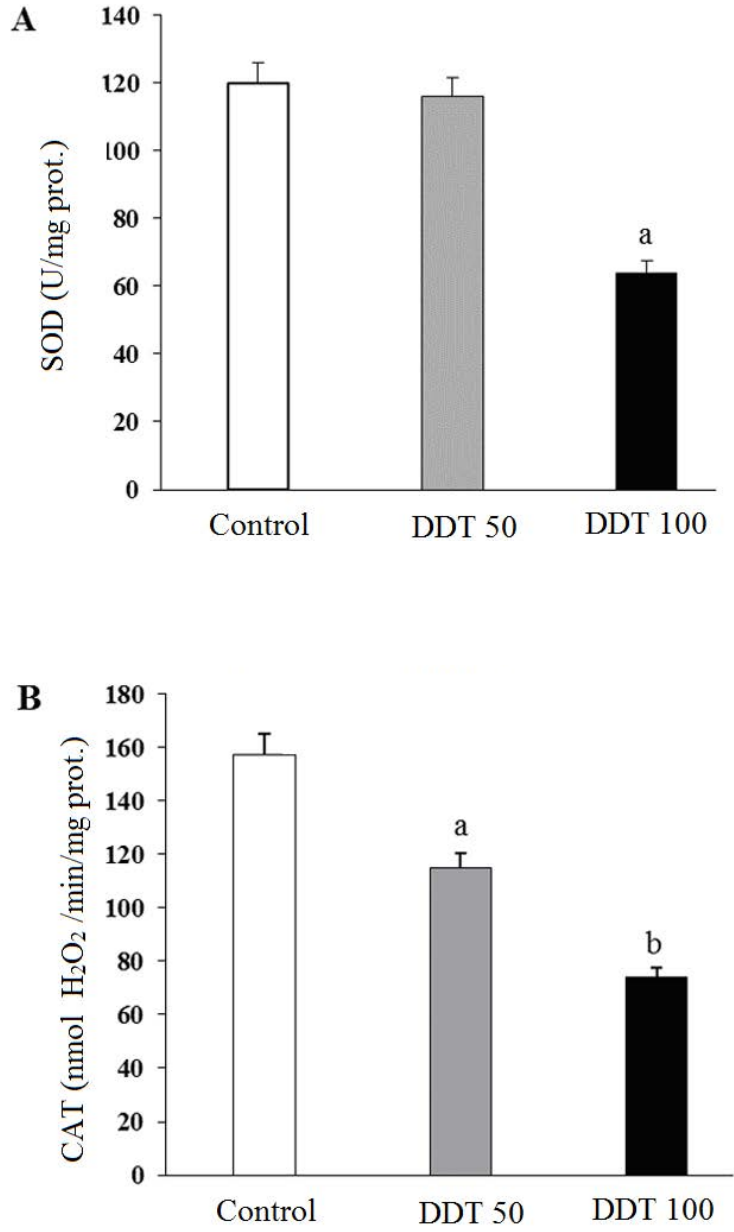

Figure 5. Effect of DDT on antioxidant activities of enzymes superoxide dismutase (SOD, A) and catalase (CAT, B) in kidney of adult rat. Each value is the mean \pm SEM of 8 determinations. Rats received an i.p. injection of 50 (DDT 50) or 100 (DDT 100) $\mathrm{mg} /$ $\mathrm{kg}$ body weight of DDT during 10 days. Control animals received the vehicle. ${ }^{\mathrm{a}, \mathrm{b}} p<0.05$ compared with controls (Tukey's multiple comparison post hoc test). rats exposed to $50 \mathrm{mg}$ of DDT/kg showed a congested blood vessels, tubular dilatation due to the accumulation of hyaline droplets in renal tubule, tubular epithelium desquamation and vacuolization of tubular lumen (Fig. 6C, D). Histopathological changes in kidney were more pronounced in the DDT 100 group. We showed atrophy of glomerulus, degeneration of renal tubules, extensive necrosis and increased of hyaline droplets (Fig. 6E, F).

\section{TUNEL assay}

Apoptosis was characterized by a TUNEL technique that specifically detects apoptotic cells in kidney. Untreated rats showed no kidney tubular cells apoptosis (Fig. 7A, B), whereas positive staining in renal tubular cells was found after treated with $50 \mathrm{mg}$ of DDT/kg (Fig. 7C, D). With DDT 100, strong positive staining was observed in renal tubular cells (Fig. 7E, F). The apoptotic index grew 35.6-fold $(p<0.01)$ and 118 -fold $(p<0.01)$ in cortex and 135-fold $(p<$ $0.01)$ and 247.5-fold $(p<0.01)$ in medulla of treated rats with 50 and $100 \mathrm{mg}$ of DDT/kg, respectively, compared to control (Table 2). Vitamin C administrated in DDT-treated rats improved significantly the apoptotic index compared with control values. The apoptotic index in kidney was returned to control values in DDT+VitC group (Table 2).

\section{Discussion}

The aim of this study was to investigate whether p,p'-DDT treatment has the ability to cause nephrotoxicity and if so, whether it is linked to oxidative stress and apoptosis. Kidney is vulnerable to damage due to perfusion and the increased concentration of excreted compounds that occur in renal tubular cells (Mohamed et al. 2003). Plasma levels of urea and creatinine are used as indicators of renal function. The creatinine excretion is dependent almost on the process of 

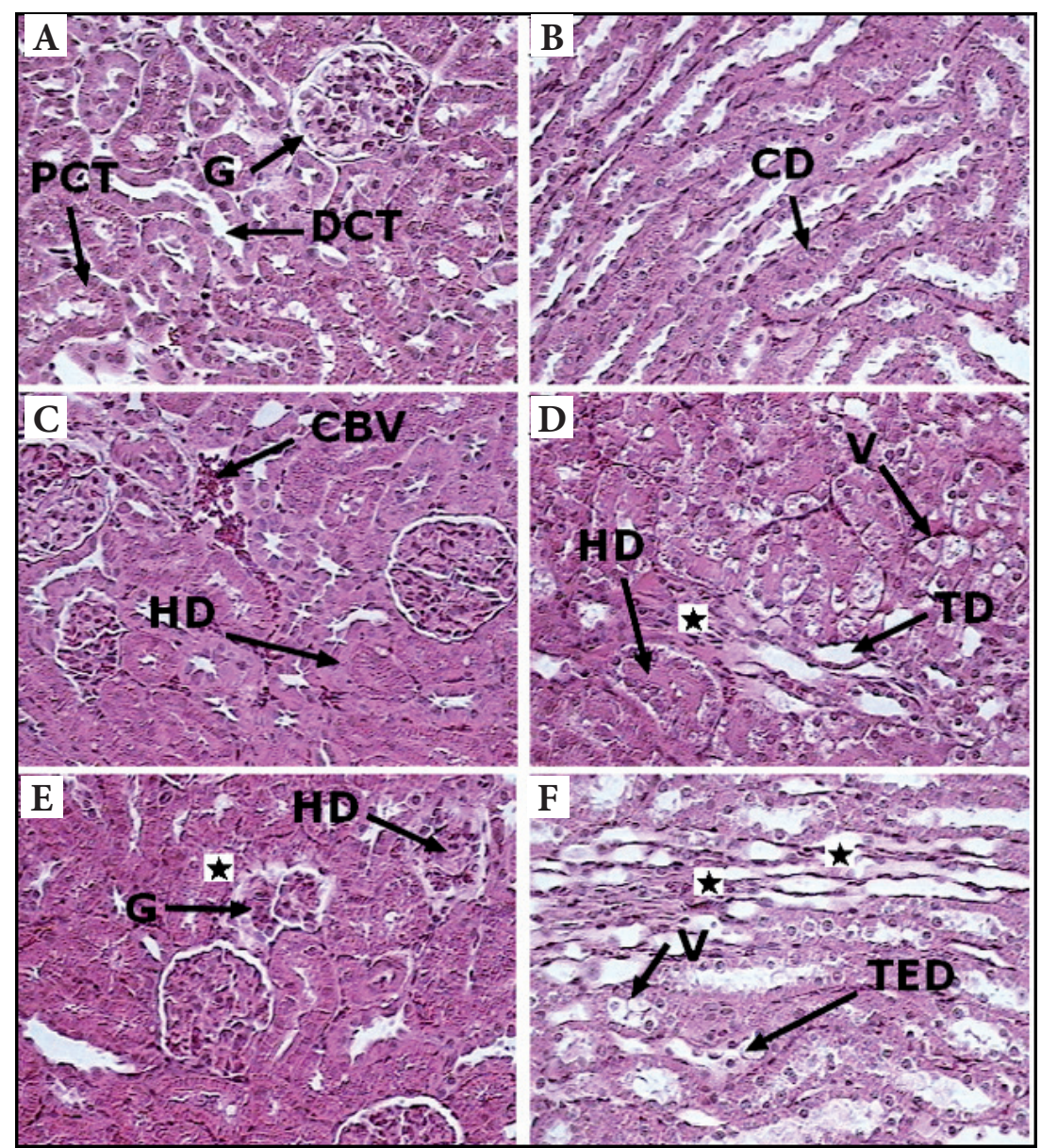

Figure 6. Photomicrographs of kidney sections of control and DDT-treated rats. A., B. Kidney of control rats showing normal architecture (A, cortex; B, medulla). C., D. Kidney of DDT-treated rats $(50 \mathrm{mg} / \mathrm{kg})$ showing congested blood vessels, accumulation of hyaline droplets in renal tubule, tubular epithelium desquamation and vacuolization of tubular lumen (C, cortex; D, medulla). E., F. Kidney of DDT-treated rats $(100 \mathrm{mg} / \mathrm{kg})$ showing a degeneration of renal tubules with extensive necrosis, increased of hyaline droplets and atrophy of glomerulus (E, cortex; F, medulla). Rats received an i.p. injection of 50 or $100 \mathrm{mg} / \mathrm{kg}$ body weight of DDT during 10 days. G, glomerulus; PCT, proximal convoluted tubule; DCT, distal convoluted tubule; $\mathrm{CD}$, collecting duct; $\mathrm{HD}$, hyaline droplets; $\mathrm{CBV}$, congested blood vessels; TD, tubular dilatation; TED, tubular epithelium desquamation; $\mathrm{V}$, vacuolization of tubular lumen; $\star$ point to necrosis. Magnification: $\times 400$. glomerular filtration, though tubular secretion contributes slightly (Kassirer 1971). High blood creatinine levels could indicate an inability of the kidney to excrete creatinine, resulting from renal disease mostly impairment of the glomerular function and tubular damage (Marks and Lieberman 2009). So any damage to kidney will show an improper excretion of creatinine. The present study showed that exposure of rats to 50 and $100 \mathrm{mg}$ of DDT/kg b.w., during 10 consecutive days, significantly increased serum creatinine and urea levels. Urea is an end product of protein and amino acid metabolism. Kidney filters excess urea into the urine and in sweat, but some goes into the bloodstream as serum urea. It is a well-known fact that, if blood urea levels are low, a problem centred in the liver might be suspected because urea is produced in the liver. Conversely, high blood levels of urea suggest that the kidney is not excreting urea normally (Vanholder et al. 1992). Thus, in this study increased serum creatinine and urea levels reflect the diagnosis of renal failure. Our study is concomitant with previous reports showing an important increase in serum creatinine and urea levels in rats exposed to $100 \mathrm{mg}$ of DDT/ kg/day (Mohammed et al. 2012). Vijaya Padma et al. (2011) have also reported increased levels of serum creatinine and urea in lindane-exposed rats. Shah and Iqbal (2010) also revealed an increased level of serum creatinine and urea in rats exposed to 10,15 and $30 \mathrm{mg}$ of diazinon $/ \mathrm{kg}$ for 8 weeks.

Table 2. Effect of DDT and vitamin C treatment on apoptotic index in kidney of adult rat

\begin{tabular}{lcc}
\hline & \multicolumn{2}{c}{ Apoptotic index (\%) } \\
\cline { 2 - 3 } & \multicolumn{1}{c}{ Cortex } & Medulla \\
\hline Control & $0.31 \pm 0.03$ & $0.16 \pm 0.01$ \\
DDT 50 & $10.1 \pm 1.11^{\mathrm{a}}$ & $21.61 \pm 1.91^{\mathrm{a}}$ \\
DDT 100 & $36.61 \pm 2.93^{\mathrm{b}}$ & $39.6 \pm 3.57^{\mathrm{b}}$ \\
DDT+VitC & $0.40 \pm 0.05^{\mathrm{c}}$ & $0.22 \pm 0.03^{\mathrm{c}}$ \\
\hline
\end{tabular}

Each value is the mean \pm SEM of 8 determinations. Rats received an i.p. injection of 50 (DDT 50) or 100 (DDT 100) $\mathrm{mg} / \mathrm{kg}$ body weight of DDT during 10 days. DDT+VitC, rats received an i.p. injection of $100 \mathrm{mg}$ of DDT $/ \mathrm{kg}$ followed by vitamin C $(200 \mathrm{mg} / \mathrm{kg})$. Control animals received the vehicle. ${ }^{\mathrm{a}} p<0.01 ;{ }^{\mathrm{b}} p<0.001$ compared with controls (Tukey's multiple comparison post hoc test). ${ }^{\mathrm{c}} p<0.01$ compared with DDT 100 group (Tukey's multiple comparison post hoc test). 

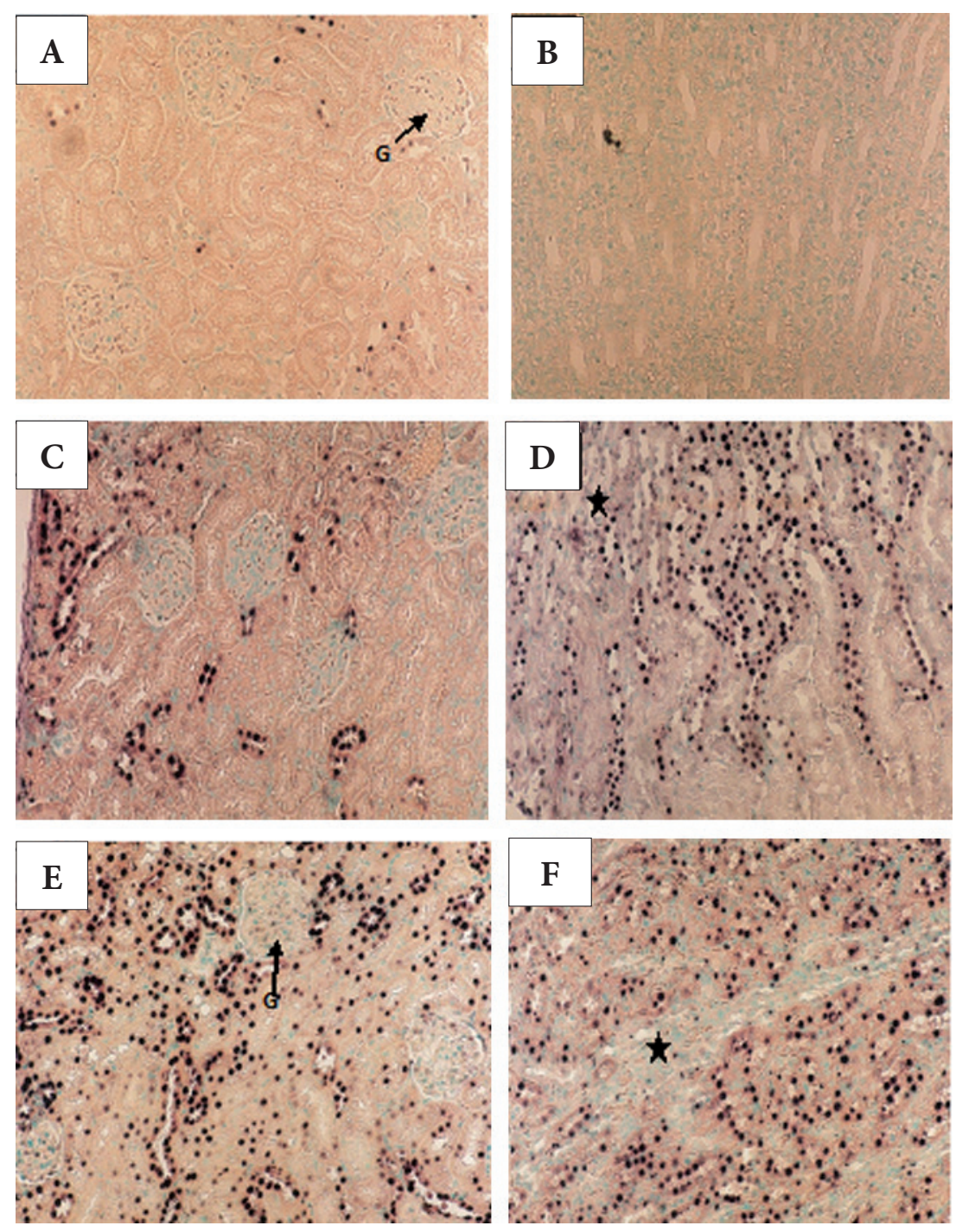

Figure 7. Detection of apoptotic cells in the kidney of rats as revealed by TUNEL assay. Kidney of control rats showed no apoptotic cells in cortex (A) and medulla (B). Kidney of DDT-treated rats with $50 \mathrm{mg} / \mathrm{kg}$ in cortex (C) and medulla (D), and $100 \mathrm{mg} /$ $\mathrm{kg}$ in cortex (E) and medulla (F) showed TUNEL-positive germ cells. Rats received an i.p. injection of $100 \mathrm{mg} / \mathrm{kg}$ body weight of DDT during 10 days. G, glomerulus; $\star$ point to necrosis. Magnification: $\times 250$.
In the present study, we hypothesized an oxidative stress-like as a potential mechanism inductor of renal injury. ROS have been implicated in several renal diseases induced by some pesticides (Shah and Iqbal 2010; Vijaya Padma et al. 2011; Wei et al. 2014). In turn, ROS are capable of initiating and promoting oxidative damage as LPO (Kovacic and Cooksy 2005). LPO is known to cause cellular injury by inactivation of membrane enzymes and receptors, depolymerisation of polysaccharide, as well as protein cross-linking and fragmentation (Luqman and Rizvi 2006). MDA is a parameter to measure lipid peroxidation and its increase is a direct result of free radical damage to membrane components of the cells. Our data indicated that sub-acute treatment of DDT significantly increased MDA level in kidney tissues of treated rats, which is an indicator of increased oxygen free radical generated by pesticides. Under this situation, stable products like carbonyl groups are produced by ROS action on proteins, also making protein carbonylation a reliable marker of oxidative stress. In the current study, we found that DDT-induced renal dysfunction is associated with oxidant damage, which was evident by increased LPO and protein carbonyl content. Our results confirmed previous data of Mohammed et al. (2012) who have also reported increased level of MDA in the kidney from rats following a single dose of DDT (100 mg/kg). Our finding was in accordance with previous studies using other organochlorines pesticides and has also reported increased MDA level in the kidney of treated rats (Shah and Iqbal 2010; Vijaya Padma et al. 2011; Wei et al. 2014). Induction of cytochrome P450 and other microsomal enzyme by various pesticides such as carbamate, has been reported and it is possible that DDT mediated free radical generation could be through induction of these enzyme (Puatanochokchai et al. 2006). Vitamin $\mathrm{C}$ administration to DDT-treated rats resulted in 
a significant decrease in LPO level compared to rats treated with DDT alone. These results are similar to the observation of another study where vitamin $\mathrm{C}$ was shown to decrease LPO level in deltamethrin-induced damage in rats (Mongi et al. 2011). The protective effect of vitamin C, observed in our study, could be important for protecting the different tissues against the oxidative injury following the use of DDT. MTs are members of a family of low molecular weight proteins rich in cysteine that play a key role in transport of essential heavy metals, detoxification of toxic metals and protection of cells against oxidation stress. We have demonstrated that the levels of MTs decreased in a dose-dependent manner in the kidney of DDT-treated rats. The inhibited level of MTs is closely associated with increased formation of ROS and reactive nitrogen species, respectively. Excessive production of these harmful substances along with a reduction in antioxidants could reduce the level of MTs in kidney (Chin et al. 1993). Antioxidant enzymes, such as SOD and CAT, are essential parts in the cellular defense against free radical-mediated tissue or cellular damage. Our results revealed a decrease in the level of SOD and CAT activities in the kidney of DDT-treated rats. Similarly, recent studies showed that exposure to pesticides (diazinon, lindane and paraquat) decreased SOD and CAT activities in rat kidney (Shah and Iqbal 2010; Vijaya Padma et al. 2011; Wei et al. 2014). SOD plays a vital role in the balance between oxidation and antioxidation. SOD catalyzes the dismutation of superoxide anions into $\mathrm{H}_{2} \mathrm{O}_{2}$ and eliminates the cytotoxic effects of the superoxide anion (Medinas and Augusto 2010). CAT is a ubiquitous enzyme that prevents cell oxidative damage by degrading $\mathrm{H}_{2} \mathrm{O}_{2}$ to $\mathrm{H}_{2} \mathrm{O}$ and $\mathrm{O}_{2}$ with high efficiency (Alfonso-Prieto et al. 2009). The balance of theses enzymes systems may be essential to renal health. Hence, the significant reduction in enzymes activities, accompanied by marked increase lipid peroxidation, may reflect adverse effects of DDT on the antioxidant system (Shi et al. 2013). Therefore, the decrease in SOD and CAT activities may explain the early-elevated ROS levels, since it was a crucial enzyme involved in the detoxification of ROS. The decrease in the amount of antioxidant enzymes (SOD and CAT) are marked through their modification in gene expression, decreased uptake or when cells are overloaded with oxidants (Barber and Harris 1994). ROS, on the other hand, possess the ability to sufficiently modify a protein, leading to altered enzyme activity (Bellomo et al. 1983). The decreased enzymes activities in DDT-treated rats may be due to the inactivation of the corresponding gene segment from which the respective enzymes are encoded. Moreover, our results showed that p,p'-DDT administration decreased renal GR and GSH activities while increased the ratio GSSG/GSH, which led to the production of free radicals and causing lipid peroxidation (Nehru and Bansal 1997). GSH is one of the most important non-enzymatic antioxidant against cellular damage produced by ROS (Luberda 2005). In its reduced form, it is necessary for the detoxification of xenobiotics. Various pesticides have been shown to decrease GSH levels. This reduction in GSH level could be due to direct conjugation of GSH with electrophiles whose increased production may result from pesticide exposure or could be due to inhibition of enzymes, like glutathione reductase, glutathione peroxidase, glucose-6-phosphate dehydrogenase, etc. which are involved in GSH synthesis and regeneration (Reed 1990). GSH is also GST co-substrate. GST is a potent antioxidant that provides cells with a substantial degree of protection against oxidative stress. It catalyzes the conjugation of reduced glutathione with a variety of endogenous compounds and xenobiotics (Romeu et al. 2002). In the current study, GST and GPx activities increased with the dose of $50 \mathrm{mg} / \mathrm{kg}$ whereas declined with the highest dose $(100 \mathrm{mg} / \mathrm{kg})$. The increased level of GST and GPx may be the adaptive response of the body to ROS attack. However, these increases were not sufficient to protect the membrane lipid which was evident by increased LPO in DDT-treated rats. At the high dose of DDT, a severe oxidative stress may suppress GSH, GST and GPx levels due to the loss of adaptive mechanisms and the oxidation of GSH to GSSG. The decrements in GST and GPx following exposure to DDT may lead to accumulation of peroxides (Shah and Iqbal 2010). Therefore, a depression in GSH levels together with GST and GPx activities makes the cells more susceptible to the attack by toxic compounds (Boesch-Saadatmandi et al. 2008). In the present study, the decrease in GPx, GST and GSH activities, accompanied by the increase of GSSG/GSH ratio and MDA levels, supports that oxidative stress is produced due to DDT administration. Moreover, histological changes were observed in the kidney of treated animals, including congested blood vessels, atrophy of glomerulus, degeneration of renal tubules, extensive necrosis and increased of hyaline droplets. The occurrence of damage to the renal tubular cells and necrosis has been associated with the administration of DDT (Mohammed et al. 2012) and other organochlorine pesticides (Shah and Iqbal 2010; Wei et al. 2014). It is known that when ROS generation overloads the antioxidant defence, the free radicals accumulated in kidney can then interact with endogenous macromolecules, alter the renal cellular function and cause necrotic renal cells (Muthukumaran et al. 2008). For this, oxidative stress seems to be one contributor to DDT-induced nephrotoxicity. Apoptosis plays an important role in the pathogenesis of a variety of renal diseases (Ueda et al. 2000). Intervention of cell apoptosis and apoptosisrelated genes may be an effective method to prevent and cure renal diseases (Rana et al. 2001). In the present study, histological examination of kidney tissue by the TUNEL method showed that apoptosis cells occurred in the tubular cells of DDT-treated rats. Also, the apoptotic index was 
significantly increased in kidney tissues of DDT-treated rats. However, vitamin C supplementation to the DDT-treated rats decreased the apoptotic index in kidney. Apoptosis is a complex event regulated by a well-tuned balance of inducer and repressor factors, such as the Bcl-2 family, which is a pivotal integrator of survival and death signal. In addition, the Fas system is a widely recognized apoptosis signal transduction pathway in which a ligand-receptor interaction triggers the cell death pathway (Feng et al. 2004). Fas is a surface receptor that triggers apoptotic cell death when cross-linked by FasL (Nagata 1997). Ligation of FasL to Fas in the cell membrane triggers activation of caspase-8. Once activated, caspase- 8 transduces a signal to effector caspases, including caspases 3, 6, and 7, and eventually leads to the hydrolysis of cytosolic and nuclear substrates (De Maria et al. 1997). There were many toxicological studies indicated that DDT or its metabolite contributed to cell apoptosis by activation of multiple caspase-mediated mechanisms, including both of the extrinsic and intrinsic apoptosis pathway. In fact, Frigo and co-worker (2005) revealed that DDT induced both the expression of the death ligand TNF-alpha and apoptosis in human embryonic kidney cells through a p38 MAPK-dependent mechanism. Recently, it was reported that p,p'-DDT activated NF- $\kappa$ B/FasL pathway and mitochondrial pathway in human liver cells which were mediated by ROS (Jin et al. 2014). Zhao and co-worker (2012) reported that the enantioselective apoptosis caused by DDT might involve three signalling pathways via caspase 3, tumor protein 53 and NF- $\kappa$ B. Previous studies showed that p,p'-DDE led to apoptosis of cultured rat Sertoli cells via mitochondria-mediated or FasL-dependent pathway (Song et al. 2008; Shi et al. 2010). Fewer study elucidated the mechanism of DDT-induced apoptosis in kidney. So, in this study, we showed for the first time that p,p'-DDT treatment induced apoptosis in renal tubular cells. These findings suggested that p,p'-DDT induced apoptosis of renal tubular cells through mitochondria-mediated and FasL-dependent pathway. It has been reported that different stimuli such as DNA damage or increased ROS level caused by DDT might trigger of both Bax activation via acting diverse molecules such as p53, and Fas system. Activation of Bax protein leads to the formation of pores in the mitochondria and results in the collapse of the electro chemical gradient across the mitochondrial membrane, then cytochrome $c$ is released into cytoplasm where it is associated with procaspase-9/Apaf-1. This complex, in turn, activates a downstream caspase program that ultimately leads to apoptotic cell death. In conclusion, the results obtained from the present study demonstrate that the sub-acute treatment of p,p'-DDT causes renal injury and apoptotic cell death in kidney tissues probably mediated by oxidative stress which may be the chief mechanism of DDT-induced nephrotoxicity in rats.
Acknowledgments. This work was supported by the Tunisian Ministry of Higher Education, Scientific Research and Technology and Carthage University. The authors thank B. Azib for his excellent technical assistance.

\section{References}

Aebi H. (1984): Catalase in vitro. Methods Enzymol. 105, $121-126$ https://doi.org/10.1016/S0076-6879(84)05016-3

Alfonso-Prieto M., Biarnes X., Vidossich P., Rovira C. (2009): The molecular mechanism of the catalase reaction. J. Am. Chem. Soc. 131, 11751-11761 https://doi.org/10.1021/ja9018572

Aksoy N., Vural H., Sabuncu T., Arslan O., Aksoy S. (2005): Beneficial effects of vitamins $\mathrm{C}$ and $\mathrm{E}$ against oxidative stress in diabetic rats. Nutr. Res. 25, 625-630 https://doi.org/10.1016/j.nutres.2005.05.005

Aulakh R. S., Bedi J. S., Gill J. P. S., Joia B. S., Pooni P. A., Sharma J. K. (2007): Occurrence of DDT and HCH insecticide residues in human biopsy adipose tissues in Punjab, India. Bull. Environ. Contam. Toxicol. 78, 330-334 https://doi.org/10.1007/s00128-007-9187-6

Barber D. A., Harris S. R. (1994): Oxygen free radicals and antioxidants: a review. Am. Pharm. 34, 26-35 https://doi.org/10.1016/S0160-3450(15)30310-X

Bellomo G., Mirabelli F., Richelmi P., Orrenius S. (1983): Critical role of sulphhydryl groups(s) in the ATP-dependent Ca2+ sequestration by the plasma membrane fraction from rat liver. FEBS Lett. 163, 136-139 https://doi.org/10.1016/0014-5793(83)81180-6

Ben Rhouma K., Tebourbi O., Krichah R., Sakly M. (2001): Reproductive toxicity of DDT in adult male rats. Hum. Exp. Toxicol. 20, 393-397 https://doi.org/10.1191/096032701682692946

Beytut E., Aksakal M. (2003): Effects of dietary vitamin E and selenium on oxidative defense mechanisms in the liver of rats treated with high doses of glucocorticoid. Biol. Trace Elem. Res. 91, 231-241 https://doi.org/10.1385/BTER:91:3:231

Boesch-Saadatmandi C., Loboda A., Jozkowicz A., Huebbe P., Blank R., Wolffram S., Dulak J., Rimbach G. (2008): Effect of ochratoxin A on redox-regulated transcription factors, antioxidant enzymes and glutathione-S-transferase in cultured kidney tubulus cells. Food Chem. Toxicol. 46, 2665-2671 https://doi.org/10.1016/j.fct.2008.04.023

Buege J. A., Aust S. D. (1976): Lactoperoxidase catalyzed lipid peroxidation of microsome-rich and artificial membranes. Biochim. Biophys. Acta 444, 192-201 https://doi.org/10.1016/0304-4165(76)90236-1

Calberg I., Mannervik B. (1985): Glutathione reductase. Methods Enzymol. 113, 484-490 https://doi.org/10.1016/S0076-6879(85)13062-4

Chin J. L., Banerjee D., Kadhim S. A., Kontozoglou T. E., Chauvin P. J., Cherian M. G. (1993): Metallothionein in testicular germ cell tumors and drug resistance. Cancer 72, 3029-3035 
https://doi.org/10.1002/1097-0142(19931115)72:10<3029::AID-CNCR2820721027>3.0.CO;2-6

De Maria R., Lenti L., Malisan F., d'Agostino F., Tomassini B., Zeuner A., Rippo M. R., Testi R. (1997): Requirement for GD3 ganglioside in CD95- and ceramide-induced apoptosis. Science 277, 1652-1655 https://doi.org/10.1126/science.277.5332.1652

Eaton D. L., Cherian M. G. (1991): Determination of metallothionein in tissues by cadmium-hemoglobin affinity assay. Methods Enzymol. 205, 83-88 https://doi.org/10.1016/0076-6879(91)05089-E

Feng H., Zeng Y., Graner W. M., Whitesell L., Katsanis E. (2004): Evidence for a novel, caspase-8-independent, Fas death domain-mediated apoptotic pathway. J. Biomed. Biotechnol. 2004, 41-51 https://doi.org/10.1155/S1110724304308041

Frigo D. E., Vigh K. A., Struckhoff A. P., Elliott S., Beckman B. S., Burow M. E., McLachlan J. A. (2005): Xenobiotic-induced TNF-alpha expression and apoptosis through the p38 MAPK signaling pathway. Toxicol. Lett. 155, 227-238 https://doi.org/10.1016/j.toxlet.2004.09.008

Habig W. H., Pabst M. J., Jakoby W. B. (1974): Glutathione S-transferases. The first enzymatic step in mercapturic acid formation. J. Biol. Chem. 249, 7130-7139

Harada T. S., Yamaguchi R., Ohtsuka M., Takeda H., Fujisawa T., Yoshida A., Enomoto A., Chiba Y., Fukumori J., Kojima S., Tomiyama N., Saka M., Ozaki M., Maita K. (2003): Mechanisms of promotion and progression of preneoplastic lesions in hepatocarcinogenesis by DDT in F344 rats. Toxicol. Pathol. 31, 87-98 https://doi.org/10.1080/01926230390173941

Hillman J. (1998): Insecticides. In: Hamilton and Hardy's industrial Toxicology. 5th editionn (Ed. R. D. Harbison), pp. 414-428, Mosby-Year Book, MO, USA

Hissin P. J., Hilf R. (1976): Fluorometric method for determination of oxidized and reduced glutathione in tissues. Anal. Biochem. 74, 214-226 https://doi.org/10.1016/0003-2697(76)90326-2

Jin X. T., Song L., Zhao J. Y., Li Z. Y., Zhao M. R., Liu W. P. (2014): Dichlorodiphenyltrichloroethane exposure induces the growth of hepatocellular carcinoma via Wnt/b-catenin pathway. Toxicol. Lett. 225, 158-166 https://doi.org/10.1016/j.toxlet.2013.12.006

Kassirer J. P. (1971): Clinical evaluation of kidney function-glomerular function. N. Engl. J. Med. 285, 385-389 https://doi.org/10.1056/NEJM197108122850706

Kovacic P., Cooksy A. (2005): Iminium metabolite mechanism for nicotine toxicity and addiction: oxidative stress and electron transfer. Med. Hypotheses 64, 104-111

https://doi.org/10.1016/j.mehy.2004.03.048

Ledirac N., Antherieu S., Dupuy A., Caron J., Rahmani R. (2005): Effects of organochlorine insecticides on MAP kinase pathways in human keratinocytes: key role of reactive oxygen species. Toxicol. Sci. 86, 444-452 https://doi.org/10.1093/toxsci/kfi192

Levine R. L., Garland D., Olivier C. N., Amici A., Climent I., Lenz A. G., Ahn B. W., Shaltiel S., Stadtman E. R. (1990): Determination of carbonyl content in oxidatively modified proteins. Methods Enzymol. 186,460-464 https://doi.org/10.1016/0076-6879(90)86141-h

Luberda Z. (2005): The role of glutathione in mammalian gametes. Reprod. Biol. 5, 5-17

Luo J., Tsuji T., Yasuda H., Sun Y., Fujigaki Y., Hishida A. (2008) : The molecular mechanisms of the attenuation of cisplatin-induced acute renal failure by $\mathrm{N}$-acetylcysteine in rats. Nephrol. Dial. Transplant. 23, 2198-2205 https://doi.org/10.1093/ndt/gfn090

Luqman S., Rizvi S. I. (2006): Protection of lipid peroxidation and carbonyl formation in proteins by capsaicin in human erythrocytes subjected to oxidative stress. Phytother. Res. 20, 303-306 https://doi.org/10.1002/ptr.1861

Malarvannan G., Kunisue T., Isobe T., Sudaryanto A., Takahashi S., Prudente M., Subramanian A., Tanabe S. (2009): Organohalogen compounds in human breast milk from mothers living in Payatas and Malate, the Philippines: levels, accumulation kinetics and infant health risk. Environ. Pollut. 157, 1924-1932 https://doi.org/10.1016/j.envpol.2009.01.010

Marklund S., Marklund G. (1974): Involvement of the superoxide anion radical in the autoxidation of pyrogallol and a convenient assay for superoxide dismutase. Eur. J. Biochem. 47, 469-474 https://doi.org/10.1111/j.1432-1033.1974.tb03714.x

Marks A. D., Lieberman M. (2009): Marks' Basic Biochemistry: a Clinical Approach. Lippincott Williams and Wilkins publication, New York

Medinas D. B., Augusto O. (2010): Mechanism of the peroxidase activity of superoxide dismutase 1. Free Radic. Biol. Med. 49, 683-684

https://doi.org/10.1016/j.freeradbiomed.2010.04.040

Mohamed M., Abdellatif M. D., Sabar A., Elglammal M. D. (2003): Sodium fluoride ion and renal function after prolonged sevoflurane or isoflurane anaesthesia. Eng. J. Anaesth. 19, 78-83

Mohammed A. H., Al-Khishali D. K., Al-Shawi N. N. (2012): Anti-oxidant effect of silymarin against DDT-induced nephrotoxicity in rats. Kerbala Journal of Pharmaceutical Sciences 4, 136-144

Mongi S., Mahfoud M., Amel B., Kamel J., Abdelfattah el F. (2011): Protective effects of vitamin $\mathrm{C}$ against haematological and biochemical toxicity induced by deltamethrin in male Wistar rats. Ecotoxicol. Environ. Saf. 74, 1765-1769

https://doi.org/10.1016/j.ecoenv.2011.04.003

Muralidharan S., Dhananjayan V., Jayanthi P. (2009): Organochlorine pesticides in commercial marine fishes of Coimbatore, India and their suitability for human consumption. Environ. Res. 109, 15-21 https://doi.org/10.1016/j.envres.2008.08.006

Muthukumaran S., Sudheer A., Menon V. P., Nalini N. (2008): Protective effect of quercetin on nicotine-induced prooxidant and antioxidant imbalance and DNA damage in Wistar rats. Toxicology 243, 207-215 https://doi.org/10.1016/j.tox.2007.10.006

Nagata S. (1997): Apoptosis by death factor. Cell 88, 355-365 https://doi.org/10.1016/S0092-8674(00)81874-7 
Nehru L. B., Bansal M. P. (1997): Effect of selenium supplementation on the glutathione redox system in the kidney of mice after chronic cadmium exposures. J. App. Toxicol. 17, 81-84 https://doi.org/10.1002/(SICI)1099-1263(199701)17:1<81::AID-JAT398>3.0.CO;2-K

Paglia D. E., Valentine W. N. (1967): Studies on the quantitative and qualitative characterization of erythrocyte glutathione peroxidase. J. Lab. Clin. Med. 70, 158-169

Parvez S., Raisuddin S. (2005): Protein carbonyls: novel biomarkers of exposure to oxidative stress-inducing pesticides in freshwater fish Channa Punctata (Bloch). Environ. Toxicol. Pharmacol. 20, $112-117$ https://doi.org/10.1016/j.etap.2004.11.002

Puatanochokchai R., Morimura K., Wanibuchi H. (2006): Alphabenzene hexachloride exert hormesis in preneoplastic lesion formation of rat hepatocarcinogenesis with the possible role for hepatic detoxifying enzymes. Cancer Lett. 240, 102-113 https://doi.org/10.1016/j.canlet.2005.09.006

Rana A., Sathyanarayana P., Lieberthal W. (2001): Role of apoptosis of renal tubular cells in acute renal failure: therapeutic implications. Apoptosis 6, 83-102 https://doi.org/10.1023/A:1009680229931

Reed D. J. (1990): Glutathione: toxicological implications. Annu. Rev. Pharmacol. Toxicol. 30, 603-631 https://doi.org/10.1146/annurev.pa.30.040190.003131

Romeu M., Mulero M., Giralt M., Folch J., Nogués M. R., Torres A., Fortu-o A., Sureda F. X., Cabré M., Paternáin J. L., Mallol J. (2002): Parameters related to free radicals in erythrocytes, plasma and epidermis of the hairless rat. Life Sci. 71, 1739-1749 https://doi.org/10.1016/S0024-3205(02)01946-X

Shah M. D., Iqbal M. (2010): Diazinon-induced oxidative stress and renal dysfunction in rats. Food Chem. Toxicol. 48, 3345-3353 https://doi.org/10.1016/j.fct.2010.09.003

Shi Y. Q., Li H. W., Wang Y. P., Liu C. J., Yang K. D. (2013): p,p'-DDE induces apoptosis and mRNA expression of apoptosis-associated genes in testes of pubertal rats. Environ. Toxicol. 28, 31-41 https://doi.org/10.1002/tox.20694

Shi Y. Q., Wang Y. P., Song Y., Li H. W., Liu C. J., Wu Z. G., Yang K. D. (2010): p,p-DDE induces testicular apoptosis in prepubertal rats via the Fas/FasL pathway. Toxicol. Lett. 193, 79-85 https://doi.org/10.1016/j.toxlet.2009.12.008
Song Y., Liang X., Hu Y., Wang Y., Yu H., Yang K. (2008): p,p'-DDE induces mitochondria-mediated apoptosis of cultured rat Sertoli cells. Toxicology 253, 53-61

https://doi.org/10.1016/j.tox.2008.08.013

Spencer P., Schaumburg H. H. (2000): Dichlorodiphenltricloroethane and derivatives. In: Experimental and Clinical Neurotoxicology. (Eds. P. Spencer and H.H. Schaumburg), pp. 478-483, Oxford Universities Press, NY, USA

Tebourbi O., Hallègue D., Yacoubi M. T., Sakly M., Ben Rhouma K. (2010): Subacute toxicity of p,p-DDT on rat thyroid: Hormonal and histopathological changes. Environ. Toxicol. Pharmacol. 29, 271-279 https://doi.org/10.1016/j.etap.2010.03.002

Ueda N., Kaushal G. P., Shah V. (2000): Apoptotic mechanisms in acute renal failure. Am. J. Med. 108, 403-415 https://doi.org/10.1016/S0002-9343(00)00311-9

Vanholder R. C., De Smet R. V., Ringoir S. M. (1992): Assessment of urea and other uremic markers for quantification of dialysis efficacy. Clin. Chem. 38, 1429-1436

Vijaya Padma V., Sowmya P., Arun Felix T., Baskaran R., Poornima P. (2011): Protective effect of gallic acid against lindane induced toxicity in experimental rats. Food Chem. Toxicol. 49, 991-998 https://doi.org/10.1016/j.fct.2011.01.005

Wei T., Tian W., Liu F., Xie G. (2014): Protective effects of exogenous $\beta$-hydroxybutyrate on paraquat toxicity in rat kidney. Biochem. Biophys. Res. Commun. 447, 666-671 https://doi.org/10.1016/j.bbrc.2014.04.074

WHO World Health Organisation (1979): DDT and its derivatives. Vol. 9, pp. 7, Geneva

Wu C. C., Bratton S. B. (2013): Regulation of the intrinsic apoptosis pathway by reactive oxygen species. Antioxid. Redox Signal. 19, 546-558 https://doi.org/10.1089/ars.2012.4905

Zhao M., Wang C., Zhang C., Wen Y., Liu W. (2012): Enantioselective cytotoxicity profile of o, p'-DDT in PC 12 cells. PLoS One 7, e43823 https://doi.org/10.1371/journal.pone.0043823

Received: June 1, 2016

Final version accepted: October 13, 2016

First published online: May 4, 2017 